\title{
The Impact of Corruption on Some Aspects of the Economy
}

\author{
Basem Elmukhtar Ertimi ${ }^{1} \&$ Mohamed Ali Saeh ${ }^{2}$ \\ ${ }^{1}$ School of Business, University of New England, Armidale, Australia \\ ${ }^{2}$ School of Law, University of New England, Armidale, Australia \\ Correspondence: Basem E. Ertimi, Department of Ac Economics, School of Business, University of New \\ England, Australia. Tel: 61-46-689-7930. E-mail:beatimi@myune.edu.au
}

Received: May 11, 2013

Accepted: June 10, 2013

Online Published: July 26, 2013

doi:10.5539/ijef.v5n8p1

URL: http://dx.doi.org/10.5539/ijef.v5n8p1

\begin{abstract}
Theoretical and empirical debate on the impact of corruption on the economy remains unclear. Many studies on corruption seem that the world is occupied by two kinds of people, "sanders" and "greasers". It depends on what the meaning of "corruption" is for them. Some scholars argue that corruption is an obstacle to economic growth, whereas others believe that corruption can (in some circumstances) endorse growth. Corruption also has a negative impact on investment, Foreign Direct Investment, and economic development as a whole. Measuring corruption is still an issue for most economists due to the difficulties of defining it, and also different forms of corruption require different objective measures. Nevertheless, recently, some measures of corruption have been widely accepted and recognised by researchers. This paper is a critical review at these positions by reviewing the theoretical literature on the impact of corruption on an economy as a whole. It is concluded that there is not enough evidence to support the "greasing the wheels" hypothesis. Instead, this document reviews different measurements of corruption to reveal that corruption is harmful for the economy.
\end{abstract}

Keywords: corruption, economic growth, economic development, measurement

\section{Brief Introduction}

Corruption is not a new issue, but has continuously existed in many societies. The level of corruption grows and shrinks over time. Corruption is legally wrong, morally wrong and economically indecent. The most common definition used in literature addressing the economic impacts of corruption is "the abuse of public power for private benefit" (Tanzi, 1998, p. 552). Notwithstanding, corruption as an academic concept largely appeared in the 1960s. The theoretical model that forms the basis of much of the current economic analysis surrounding corruption is the principal- agent (PA) model. The PA model assumes that there is a divergence between the interests of the principal and those of the agent. Corruption happens when an agent deceive the principal's interest in pursuit of his or her own (Kurer, 2005). This model has been modified to include third parties and is known as the principal-agent-client (PAS) model. This model has added another dimension to the model, as he or she provides another window of opportunity for the agent to engage in corrupt practices. A "queue model" suggested by Lui (1985) describes the situation where bureaucrats allocate business licences to companies and give preferential treatment to those who bribe the bureaucrats into speeding up procedures. Another model called the "auction model", developed by Lien (1986), states that bribes in a bidding process might stimulate efficiency since the most efficient firms are habitually those who can bear the highest bribes.

\section{Measurements}

An exact measure of corruption is not easy to come by. Some organisations consider corruption as unobservable and variable; therefore, corruption is usually measured by proxies. There are four types of proxies to measure corruption, defined by World Bank, namely:
i) Macroeconomic empirical studies
ii) Survey methodology
iii) Arrests and convictions
iv) Net Asset Evaluation

Corruption cannot be measured in the same way as other economic variables. Yet, the number of indices that measure corruption has grown rapidly over the past decade. It is vital to keep in mind that there has not been an international agreement on the precise meaning of corruption, which in turn results in an ambiguity that has 
direct implications on international rankings. It is almost impossible to get an objective and precise measure for corruption due to the different faces and nature of corruption. There is difficulty in obtaining objective data on corruption, and there is still no measurement system that accounts precisely for actual levels of corruption within a certain nation and, by extension, at the international level. This is because exact measures of corruption are not well connected with the general level of corruption. However, the indicators are very beneficial in raising awareness, making statistical comparisons between countries and establishing correlations between corruption and a wide range of variables.

Empirical studies that are conducted to examine corruption rely heavily on the measures used to determine levels of corruption in a nation. Such measures are crucial in determining the value of the main explanatory variable of the study, which is the corruption level. Corruption is a term that presents a set of variables acknowledged as corrupt practices. This implies that there may be some variation in the different approaches used to measure corruption that have been established from the types of variables encompassed in the basic data for this measure. In addition, there is no agreement on how data can be collected and how is it weighted in order to form the measure. In fact, the differences in the methods for measuring corruption can influence a replication of the findings of study, due to the potential for considerably different values allocated to the explanatory variable of corruption.

Early corruption indicators were derived from either pure objective measurements or subjective measurements. Due to the criticisms surrounding these indicators by the mid-1990s, a new generation of corruption indicators appeared. This new generation of indicators was constructed by combining several primary measures together and has therefore been termed 'composite indicators', or 'aggregate indicators' (Kaufmann, and Zoido, 1999). Kaufmaan et al (2007) classify four main advantages of aggregate indicators. First, aggregate indicators have broader country coverage than individual ones. Second, they provide a functional summary of a large array of individual indicators. Third, by averaging out these indicators, measurement errors have been reduced and the influences of bias from individual sources eliminated. Lastly, aggregate indicators take into account explicit margins of error. This ensures that readers do not over-interpret small differences in the data between countries that are usually insignificant. The two most popular indicators used among anti-corruption practitioners are the CPI and the ICRG.

The most well-known global index that exists as a measure of corruption and gives complete data in a unified way is the index published by Transparency International. Established in 1993, the goal of the organisation is to shrink worldwide corruption by reporting on corrupt practices. The Corruption Perceptions Index (CPI) has been published by the organisation since 1997, ranking countries by the degree that business, politicians, public officials, and outside observers perceive corruption. Founded on surveys in a number of countries, the CPI seeks information on the frequency of bribes, the perception of corruption in public administration, and the amount of corruption that bureaucracy (Lambsdorff, 2002). Other additional sources are also used, including the Economic Intelligence Unit Data and the World Bank Business Environment Survey. The inconsistency in the nature of the compound sources in subsequent years is due to the deficiency in the methodology in developing the index, which weakens the comparison. Moreover, the number of sources used in the compound index for each nation varies. In spite of its weaknesses, the CPI is presently considered to be the best instrument available to measure the variability of corruption. Black market activity is another index that can also be used as a measurement of corruption. It is widely known as the sub-index of Economic Freedom Index (EFI). The EFI comprises a component which determines the "irregular payments" levels that occur in the economy of a country on a scale ranging from 0 to10, with 10 representing a high level of irregular payments. The component of the EFI is measuring the activity level of the black market, which acts as an indirect measure of corruption. The component of irregular payments from the EFI, however, is not available for all countries. The Global Competitiveness Report of the World Economic Forum is the only source of data for irregular payments.

An annual report issue by the Political Risk Services, International Country Risk Guide (ICRG) contains a corruption index. Tanzi and Davood (1998) have employed this in their empirical study. ICRG Governance Indicators generate comparable measures of the quality of institutions' in various countries, including perceptions of the extent to which public authority is exercised for personal benefit (including both grand and petty types of corruption). The new data have created vital macro-level estimates of the harmful effect of perceptions of corruption on investment and growth (Mauro, 1995; Kaufmann et al., 1999; and Wei, 2000).

In investigating corruption, researchers have also used other proxies for measuring corruption, Derived from the indices published by the Economist Intelligence Unit (EIU). The EIU generates a compound index for the overall risk characterised by the nation and generates indices on 56 risk factors available in various countries. Furthermore, these risk factors contain a set of specific risks such as political instability, as well as the threat of 
terrorism. Corruption is among the risk factors measured, where the level of corruption in a country is based on the analyst's perception. All are classified risk factors including corruption which has a ranking between 0 and 10.

Analysis of the deviation that occurs between the measurements is problematic because of the considerable differences in the way corruption information is collected and counted in different indices of corruption or measures. The only index where the information on corruption is presented in a unified and coherent manner is the CPI index. The data of the EIU on corruption is embedded in reports on risk factors in different nations, are relative ranking of the nations is not provided by this data. Consequently, the data must be extracted manually from the reports. Moreover, the data has not been presented in a form suitable for comparison. Likewise, the CMS does not offer cohesive data that allow exact comparisons to the EPI.

Generally, research on corruption is increasingly dependent on using the CPI as the key measure of the presence of corruption a particular country. Depending on the measures used by the researchers, this raises the question of comparison and replication in results of the study when other measurement systems are used. Despite the EIU being frequently used as the basis for gaining combined measures of corruption of the past, the development of the CPI has limited the difficulties inherent in the scattered corruption data of the EIU. This is obvious from the multifaceted technique used by Mauro in his study in 1995, which was based on the EIU as a key source of information for quantifying corruption. Accordingly, the CPI seems to be currently the most accurate measure of corruption. The use of the CPI enhances the capability of other researchers to reproduce the results of a study.

\section{The Impact of Corruption}

There is a consensus in the literature that corruption is harmful for a society. It distorts income distribution, discourages investments, causes inefficiencies and the waste of resources and harms democracy and ethics. Interestingly, there are a number of studies arguing that there might be some benefits of corruption (Leys, 1970; Leff 1964; Lui, 1985). In these studies, the argument is that corruption can serve as an incentive payment to remove government imposed inefficient rules, speeding up bureaucracy, and providing a chance to get permissions faster by paying for them. However, these studies miss a point; usually heavy bureaucracy is created by the bureaucrats to be able to gain more bribes. Conversely, the literature on the harmful effects of corruption is much broader. Many studies have shown that development negatively correlated with the level of corruption (Mauro, 1995; Le \& Rishi, 2006. Rijckeghem and Weder (2001) used panel data from 31 countries in the years between 1982 and 1994, and found a statistically significant negative relationship in the long term between corruption and the ratio of public sector employees' wage levels to the wage levels of the employees in the private productive sectors. On the other hand, authors cannot find a relationship between either corruption and education, or Gross Domestic Product per capita and corruption. In the article by Ades and Di Tella (1997) a number of panel and cross-section regressions analyses were conducted to illustrate that more active industrial policies of government were considerably associated with higher levels of corruption.

\subsection{Corruption and Economic Development}

A country's variation in economic development has been correlated with its level of corruption by most scholars who measure economic growth using Gross Domestic Product per capita, Paldam (2002), Treisman (2002) and Montinola and Jackman (2002). Consequently, these researchers discovered evidence of corruption levels declining considerably with increasing economic development. However, Kaufmann and Kraay (2003) refute the argument that higher income per capita results in lower levels of corruption and stress that economic development is a result of low corruption levels. Efforts have been made in the literature to ascertain how corruption affects the growth of the economy. With a cross section of about 97 countries, Tanzi and Davoodi (1998) obtained evidence showing that corruption lowers growth. Similar findings were reported by Leite and Weidmann (2001). Additionally, corruption could act as a tax on investment income hence creating a hostile environment for investors (Bardhan, 1997, p. 1328). It further reduces the quality of investment with the diversion of resources from their intended use into payoffs (Tanzi \& Davoodi, 1997), therefore hampering the economic development of a country. In spite of these views, some researchers argue that its impacts might not inevitably be entirely unfavorable. For example, the 'grease the wheels' hypothesis suggests that corruption can be useful for economic growth in a non-ideal world where alterations are caused by imperfect institutions (Huntington, 1968; Leff, 1964; Leys, 1965).

Corruption can evade bureaucratic rules and act as a trouble-saving device that increases efficiency and hence growth. This is because corruption becomes increaseingly costly to eliminate as it decreases, and therefore there comes a point where eliminating it will be more costly to the economy. This is evident in an empirical study by Colombatto (2003), which shows that corruption does contribute to efficiency in both developed and totalitarian 
countries.

\subsection{Corruption and Aid}

Evidence suggests that corruption is capable of reducing the effectiveness of foreign aid programs as corrupt officials often pocket the money for private purposes (Boone, 1996). Burnside and Dollar (2000) revealed that the effectiveness of foreign aid in positively affecting economic growth depends on the existence of effective institutions to implement good policies in the recipient country. Their argument rests on the fact that corrupt governments "is not going to use aid wisely and outside donors are not going to be able to force it to change its habits" (Burnside \& Dollar, 2004). This view of Burnside and Dollar (2004) has received support in the literature (Collier \& Dehn 2001; Collier \& Dollar 2002). Kaufmann et al (2006) also finds evidence that the likelihood of project success, long-term sustainability of investment and economic growth is much higher in aid-recipient countries that are less corrupt than those with high levels of corruption.

Regardless of the argument made by many international donors that their foreign aid policies favor honest governments with good policies, analyses of past aid have revealed that the intentions of this nature have not translated into actions. Alesina and Weder (2002) disagree with the statement of donors who say that they extend more aid to countries where governments are effective and honest, because the reverse was true in their findings. Similar findings were reported by Svensson (2000). However, studies also found variations in donors' willingness to reward well-governed countries with more aid. Although the level of corruption in recipient countries is not taken into account by most donor countries (Svensson, 2000; Alesina \& Weder, 2002), Australia and Scandinavia were reported to have rewarded countries for their good governance (Alesina \& Weder, 2002).

An investigation was undertaken by Alesina and Weder (1999) on whether aid from OECD countries is influenced by corrupt governments. A number of different measures of corruption were utilised in the investigation of different samples of countries. The study showed that there was not enough evidence that foreign donors discriminate against corrupt nations. Surprisingly, it is suggested that corrupt countries attract aid from OECD countries. Further investigation by Alesina and Weder (1999) on the flow of bilateral aid revealed that the provision of aid to corrupted countries is significantly avoided by Australia and the Scandinavian countries. However, the investigation showed that the US favours aid to corrupt nations. This is concluded from the significant negative coefficient in the investigation of the corruption variable. The limitation of this study is that the authors have not compared their findings with other indices, leaving room for doubt.

\subsection{Corruption and Foreign Direct Investments (FDI)}

The foreign capital in a country might be undermined by corruption. A study was conducted by Hines (1995), showing that the investors from the US varied from other countries in choosing to locate their FDI to less corrupt countries since 1978. He attributes this to the Foreign Corrupt Practices Act (FCPA). Another study was conducted by Wei (1997) to examine whether Japan has a propensity to put more money into corrupt countries. There have been other studies conducted to test the correlation between corruption and the capital inflows. Early, Wheeler and Mody (1992) have not found a strong relationship between the host countries and the size of FDI. Recently, however, studies have shown a negative correlation between them. A study undertaken by Wei (1997) revealed a significant negative effect focusing on bilateral flows between 45 host countries and 14 sources in 1990 and 1991. The study found that increasing the level of corruption from that of Mexico to that of Singapore is equal to increasing the tax rate by roughly 20 percent. Weder and Alesina (1999) used a regression of corruption on FDIs in a cross section of countries. The study concluded that the effect of corruption is significant by testing many explanatory variables and different specifications.

\subsection{The Impact of Corruption on Economic Growth (GDP)}

Regardless of the common perception that corruption is growth reducing, one of the first studies done by Leff (1964) disputed that corruption might grease the wheels of the activities of public officials in countries in which bureaucratic regulations are ponderous. This is the reason why Leff emphasises that corruption increases the social welfare. Other studies done by Huntington (1968) and Leys (1965) agree with the argument that corruption has a positive influence on economic growth. The reason is that corruption increases efficiency, particularly in the public sector. Lui, (1985) developed an equilibrium queuing model of bribery where the decision on bribe payments is decentralised to customers. Likewise, Lui demonstrated that under certain circumstances the model of bribing is capable of optimal solution to society. The author argued that the optimal speed for the private sector of the service selected by the server can be quicker than the speed without bribery. In line with this argument, Acemoglu and Verdier (1998) support the idea that corruption positively affects economic growth, and found that in an economy where contracts to boost investments are necessary, it might be best to allow certain levels of corruption and not fully implement the property rights. They also found that in 
developing countries one of the ways to encourage development is for these economies to choose more corruption and lower levels of property rights.

On the other hand, most of the studies argue that corruption leads to lower efficiency, which in turn leads to lower growth. Myrdal (1968) first investigated deliberate delays by bureaucrats in solving problems in order to attract more bribers. This argument has been sustained in recent years by a large number of experimental studies, mainly on the basis of indicators of corruption as a personal assessment of corruption levels, showing that corruption reduces economic growth and negatively affects social development.

The majority of empirical studies have explored the implications of corruption on investment, allocation of foreign direct investment, and on composition of the expenditure of the government.

The theoretical literature on the impact of corruption on the rate of economic growth indicates that the engine of growth is generally identified in the form of human capital. In the public sector, public officials create opportunities for bribery via discretionary changes of the incentive regime framed by public policies. In general, bribes are taken to avoid rent destruction or in rent seeking instead of increasing human capital. The accumulation of human capital is adversely affected as a result of this and, accordingly, there are lower the growth rates (Pecorino, 1992).

Given the perspective above, and supposing that the accumulation of human capital continuously brings a positive return, it is implied that corruption diminishes growth, and the ideal level of corruption would be zero.

Acemoglu and Verdier (1998), Huntington (1968) and Leff (1964) have disputed that corruption might increase the efficiency of the economy. They argue that this takes place through the use of speed money, which permits firms to evade bureaucratic delay by giving bribes. In 1993 Shleifer and Vishny developed a model of corruption called a principle-agent model of corruption, in which the government is the principal and the bureaucrats are agents. According to this model, the bribes are sometimes extorted at the expense of serving the interests of government when bureaucrats act in their own self-interest. As such, and by extension, it is predicted from the model that corruption would drop the efficiency in an economy. Another model constructed by Blackburn and Forgues-puccio (2009) predicted that corruption can increase (or decrease) efficiency in an economy.

Lui (1985) also argues that corruption may support market performances; good firms have the chance to avoid the heaviness of bureaucracy and take part in the market. Another view taken by Graziano (1980) and Huntington (2002) is that large-scale corruption may indirectly strengthen the links between people. People will tend to be more linked because they feel they are in the same camp, thus reducing the risk of conflict within the population. As such, the economy will grow because of this stability.

On the other hand, many studies conclude that corruption is growth reducing (Mauro (1995), Mo (2001) and Adit (2009). Shleifer and Vishney (1992) dispute that those countries in which individuals who are qualified and talented dedicate themselves to opportunist behaviours or bribing, have a relatively slower growth. Moreover, taxes remain a means by which corruption can act on economic growth. As such, tax evasion is supported by corruption, which consequently negatively affects services, the allocation of public goods and economic growth Loayza (1996). At the same time with the higher levels of corruption, the shadow economy becomes a substantial proportion of the economy and the inefficient bureaucracy increases.

Other studies have extensively investigated corruption from the perspective of the behaviour of rent seeking, where individuals or a group have the opportunity to get revenue that overdo the revenue typically available in a perfect competitive market. Antwi and Adams (2003) found that when resources from outside sources designed for the projects of urban renewal are diverted by government agencies via privileges and high salaries for administrators, few funds accomplish their intended use. Another study done by Mbaku (1999) reported that politics and the structure of the institutions in African countries enhance rent-seeking behaviour by assigning a large number of restrictions on regular economic activities. Bureaucrats take advantage of their positions by seeking gratuities for the performance of routine services which results in institutionalised and endemic corruption. A vast number of imperial studies targeted at establishing a link between the rate of economic growth and corruption have been produced as a consequence of the theoretical debate on the impact of corruption upon an economy.

\section{Conclusion}

Reviewing the recent literature regarding the relationship between corruption and economic growth, corruption appears that it can influence economic growth through several channels. Many models have been applied to measure this relationship. The most popular method is a regression model. It also appears that there are difficulties in measuring corruption which is mainly attributed to the difficulties in defining it. Using measures 
for corruption help to establish the relationship between the level of corruption and economic growth. The above literature review theory and empirical studies has presented on a particular aspect of corruption. It can be seen from the empirical studies outlined above that corruption in general is harmful to economic growth both directly and indirectly, throughout many channels such as investment, trade and foreign direct investment.

The discussion in this paper reviews the relationship between corruption and economic growth. The present study is based on the varied findings contained in the review. The review indicates that it can be theoretically and empirically proven that economic growth is undoubtedly influenced by corruption through the variables of investment, trade and FDI.

\section{References}

Acemoglu, D., \& Verdier, T. (1998). Property rights, corruption and the allocation of talent: A general equilibrium approach. The Economic Journal, 108(450), 1381-1403. http://dx.doi.org/10.1111/1468-0297.00347

Ades, A., \& Di Tella, R. (1997). The new economics of corruption: A survey and some new results. Political Studies, 45(3), 496-515. http://dx.doi.org/10.1111/1467-9248.00093

Aidt, T. S. (2009). Corruption, institutions, and economic development. Oxford Review of Economic Policy, 25(2), 271-291. http://dx.doi.org/10.1093/oxrep/grp012

Alesina, A., \& Weder, B. (1999). Do corrupt governments receive less foreign aid? National Bureau of Economic Research. http://dx.doi.org/10.3386/w7108

Alesina, A., \& Weder, B. (2002, September). Do corrupt governments receive less foreign aid? American Economic Review, 92.

Antwi, A. Y., \& Adams, J. (2003). Rent-seeking behaviour and its economic costs in urban land transactions in Accra, Ghana. Urban Studies, 40(10), 2083-2098. http://dx.doi.org/10.1080/0042098032000116121

Bardhan, P. (1997). Corruption and development: A review of issues. Journal of Economic Literature, 33(3), $1320-1346$.

Blackburn, K., \& Forgues-Puccio, G. F. (2009). Why is corruption less harmful in some countries than in others? $\begin{array}{lllll}\text { Journal of Economic Behavior \& } & \text { Organization, 72(3), }\end{array}$ http://dx.doi.org/10.1016/j.jebo.2009.08.009

Boone, P. (1996, February). Politics and the effectiveness of foreign aid. European Economic Review, 40, 289 329. http://dx.doi.org/10.1016/0014-2921(95)00127-1

Burnside, C., \& Dollar, D. (2000). Aid, policies, and growth. American Economic Review, 90(4), 847-868. http://dx.doi.org/10.1257/aer.90.4.847

Burnside, C., \& Dollar, D. (2004). Aid, policies, and growth: Reply. The American Economic Review, 94(3), 781-784. http://dx.doi.org/10.1257/0002828041464524

Collier, P., \& Dollar, D. (2001). Can the world cut poverty in half? How policy reform and effective aid can meet the international development goals. World Development, 29(11), 1787-1802. http://dx.doi.org/10.1016/S0305-750X(01)00076-6

Collier, P., \& Dollar, D. (2002). Aid allocation and poverty reduction. European Economic Review, 46(8), 14751500. http://dx.doi.org/10.1016/S0014-2921(01)00187-8

Colombatto, E. (2003). Why is corruption tolerated? The Review of Austrian Economics, 16(4), 363-379. http://dx.doi.org/10.1023/A:1027349206371

Da Cunha Leite, C., \& Weidmann, J. (2001). Does mother nature corrupt? Natural resources, corruption, and economic growth. IMF Working Paper.

Hines Jr, J. R. (1995). Forbidden payment: Foreign bribery and American business after 1977. National Bureau of Economic Research.

Huntington, S. (1968). Political order in changing societies. New Haven, CT: Yale University Press.

Kaufmann, D., \& Shang, J. W. (1999). Does grease money speed up the wheels of commerce. Working Paper 7093, National Bureau of Economic Research.

Kaufmann, D., Kraay, A., \& Mastruzzi, M. (2006). Measuring corruption: Myths and realities. Development Outreach, 8(2), 124-37. 
Kaufmann, D., Kraay, A., \& Mastruzzi, M. (2007). Governance matters VI: Governance indicators for 19962006. World Bank Policy research working paper, 4280.

Kaufmann, D., Kraay, A., \& Zoido-Lobatón, P. (2000). Governance matters. Finance \& Development, 37(2), 10.

Kurer, O. (2005). Corruption: An alternative approach to its definition and measurement. Political Studies, 53(1), 222-239. http://dx.doi.org/10.1111/j.1467-9248.2005.00525.x

Lambsdorff, J. G. (2002). Making corrupt deals: Contracting in the shadow of the law. Journal of Economic Behavior \& Organization, 48(3), 221-241. http://dx.doi.org/10.1016/S0167-2681(01)00217-7

Le Quan, V., \& Rishi, M. (2006). Corruption and capital flight: An empirical assessment. International Economic Journal, 20, 523-540. http://dx.doi.org/10.1080/10168730601027161

Leff, N. (1964). Economic development through bureaucratic corruption. American Behavioral Scientist, 82, $337-41$.

Leys, C. (1965). What is the problem about corruption? Journal of Modern African Studies, 3(2), 215-230. http://dx.doi.org/10.1017/S0022278X00023636

Leys, C. (1970). What is the problem about corruption? In A. J. Heidenheimer (Ed.), Political Corruption: Readings in Comparative Analysis (pp. 31-37).

Lien, D. H. D. (1986). A note on competitive bribery games. Economics Letters, 22(4), 337-341. http://dx.doi.org/10.1016/0165-1765(86)90093-5

Loayza, N. V. (1996). The economics of the informal sector: A simple model and some empirical evidence from Latin America. Carnegie-Rochester Conference Series on Public Policy, 45, 129-162. http://dx.doi.org/10.1016/S0167-2231(96)00021-8

Lui, F. T. (1985). An equilibrium queuing model of bribery. The Journal of Political Economy, 93(4), 760-781. http://dx.doi.org/10.1086/261329

Mauro, P. (1995). Corruption and growth. The Quarterly Journal of Economics, 110(3), 681-712. http://dx.doi.org/10.2307/2946696

Mo, P. H. (2001). Corruption and economic growth. Journal of Comparative Economics, 29(1), 66-79. http://dx.doi.org/10.1006/jcec.2000.1703

Montinola, G. R., \& Jackman, R. W. (2002). Sources of corruption: A cross-country study. British Journal of Political Science, 32(1), 147-170. http://dx.doi.org/10.1017/S0007123402000066

Mukum, M. J. (1999). Corruption cleanups in developing societies: The public choice perspective. International Journal of Public Administration, 22(2), 309-345. http://dx.doi.org/10.1080/01900699908525385

Myrdal, G. (1968), Corruption: its causes and effects. In Asian drama: An inquiry into the poverty of nations. Vol. II. New York: Pantheon. Reprinted in Political corruption: A handbook. Edited by a Heidenheimer et al. New Brunswick: Transaction Publishers, 1989: 953-961.

Paldam, M. (2002). The cross-country pattern of corruption: Economics, culture and the seesaw dynamics. European Journal of Political Economy, 18(2), 215-240. http://dx.doi.org/10.1016/S0176-2680(02)00078-2

Pecorino, P. (1992). Rent seeking and growth: The case of growth through human capital accumulation. Canadian Journal of Economics, 944-956. http://dx.doi.org/10.2307/135773

Rose-Ackerman, S. (1997). The political economy of corruption. Corruption and the global economy, 31-60.

Shleifer, A., \& Vishny, R. W. (1997). A survey of corporate governance. The Journal of Finance, 52(2), 737-783. http://dx.doi.org/10.1111/j.1540-6261.1997.tb04820.x

Svensson, J. (2000). Foreign aid and rent-seeking. Journal of International Economics, 51(2), 437-461. http://dx.doi.org/10.1016/S0022-1996(99)00014-8

Tanzi, V. (1998). Corruption around the world: Causes, consequences, scope, and cures. Staff Papers-International Monetary Fund, 559-594. http://dx.doi.org/10.2307/3867585

Tanzi, V., \& Davoodi, H. (1998). Roads to nowhere: How corruption in public investment hurts growth. The Economic Issues Series. Washington D. C.: International Monetary Fund.

Treisman, D. (2000). The causes of corruption: A cross-national study. Journal of public economics, 76(3), 399457. http://dx.doi.org/10.1016/S0047-2727(99)00092-4 
Van Rijckeghem, C., \& Weder, B. (2001). Sources of contagion: Is it finance or trade? Journal of International Economics, 54(2), 293-308. http://dx.doi.org/10.1016/S0022-1996(00)00095-7

Wei, S. J. (1997). Why is corruption so much more taxing than tax? Arbitrariness kills. National Bureau of Economic Research.

Wei, S. J. (2001). Corruption in economic transition and development: Grease or sand? U.N.

Wheeler, D., \& Mody, A. (1992). International investment location decisions: The case of US firms. Journal of International Economics, 33(1), 57-76. http://dx.doi.org/10.1016/0022-1996(92)90050-T

\section{Copyrights}

Copyright for this article is retained by the author(s), with first publication rights granted to the journal.

This is an open-access article distributed under the terms and conditions of the Creative Commons Attribution license (http://creativecommons.org/licenses/by/3.0/). 